\title{
Proposal for a Public Policy in Reference to NOM-035-STPS-2018 and SARS-CoV- 2/ COVID 19
}

\section{Propuesta de política pública en referencia a la NOM-035-STPS-2018 y al SARS- CoV-2/ COVID 19}

CARMONA-GARCÍA, Laura Georgina†*, LÓPEZ-GUZMÁN, Lorena Araceli, AGUIRRERODRÍGUEZ, Jaime and NÚÑEZ-NÚÑ̃EZ, José Alonso

\section{Universidad Autónoma de Chihuahua}

ID $1^{\text {st }}$ Author: Laura Georgina, Carmona García / ORC ID: 000-0003-0314-7895

ID $1^{\text {st }}$ Co-author: Lorena Araceli, López-Guzmán / ORC ID: 0000-0002-8238-1438

ID $2^{\text {nd }}$ Co-author: Jaime, Aguirre-Rodríguez / ORC ID: 0000-0002-1678-030X

ID $3^{\text {rd }}$ Co-author: José Alonso, Núñez-Núñez /ORCID ID: 0000-0001-8126-3360

DOI: $10.35429 /$ EJROP.2021.7.12.21.30

Received April 18, 2021; Accepted June 30, 2021

\begin{abstract}
The economic development of companies has not been simple, continuously, they have to reinvent themselves, to keep up with the requirements and national and international changes that are generated, so the present study, seeks to harmonize the guidelines of the NOM-035SPTS-2018, which generates substantial changes in the contract and management of personnel; and on the other hand, the pandemic Covid-19, which generated a special condition; The government and companies have modified their ways of working, are facing unexpected situations that adhere in several aspects to NOM-035, with the aim of seeking the proposal of a public policy to encourage such changes and alleviate the situation of public and private enterprise, which is reflected in the health and welfare of the working population, in turn achieve an economic benefit in Public Health. An analysis is made with a qualitative, exploratory documentary approach, based on the laws, articles of the organizations in charge and formal research on the subject, evaluating the possibility of creating a public policy to address this problem.
\end{abstract}

NOM-035, México, Covid-19

\begin{abstract}
Resumen
El desarrollo económico de las empresas no ha sido sencillo, continuamente, se tienen que reinventar, para estar a la altura de los requisitos y los cambios nacionales e internacionales que se generan, por lo que el presente estudio, busca armonizar los lineamientos de la NOM035-SPTS-2018, la cual genera cambios sustanciales en el contrato y manejo del personal; y por otro lado, la pandemia Covid-19, que generó una condición especial; El gobierno y las empresas han modificado sus formas de trabajo, están enfrentando situaciones inesperadas que se adhieren en varios aspectos a la NOM-035, con el objetivo de buscar la propuesta de una política pública para incentivar dichos cambios y aliviar la situación de la empresa pública y privada, que se refleja en la salud y bienestar de la población laboral, a su vez lograr un beneficio económico en la Salud Pública. Se realiza un análisis con enfoque cualitativo, exploratorio documental, basado en las leyes, artículos de los organismos encargados e investigaciones formales sobre el tema evaluando la posibilidad para crear una política pública que atienda esta problemática.
\end{abstract}

NOM-035, México, Covid-19

Citation: CARMONA-GARCÍA, Laura Georgina, LÓPEZ-GUZMÁN, Lorena Araceli, AGUIRRE-RODRÍGUEZ, Jaime and NÚÑEZ-NÚÑEZ, José Alonso. Proposal for a Public Policy in Reference to NOM-035-STPS-2018 and SARS-CoV-2/ COVID 19. ECORFAN Journal-Republic of Paraguay. 2021. 7-12: 21-30

\footnotetext{
* Correspondence to Author (email: lcarmona@uach.mx)

$\dagger$ Researcher contributing as first author.
} 


\section{1.- Introduction}

The current economic situation of companies in Mexico has been somewhat complicated, facing a scenario of uncertainty the last years 2019 , 2020 and 2021, have been difficult operationally and economically, the impact of the pandemic of COVID-19, came to modify the way of operating and interacting of companies around the world; to date it is difficult to realize the total economic impact.

Globalization has brought for Mexico, commitments, that its compliance, today becomes more urgent, as it of sustainability, which includes the issue of inclusive and decent work, understanding that it must observe, a healthy work environment in all contexts, that is why this article is reviewed in this article the NOM-035- STPS-2018, which is aimed at detecting, correcting and eliminating psychosocial risk factors in companies, as well as assessing the labor affectation and the current situation of companies in Mexico, which is in a non-beneficial scenario, so it is about verifying the possibility of a public policy as an incentive for this situation.

It is perceived that a public policy is a burden for the State, which in the same way has been affected by the pandemic, so the different panoramas are analyzed, from the international and national framework, through a documentary type research, netnographic, reviewing the formal and scientific impressions about these situations, the laws that issue the guidelines for the application of this norm, the scenarios of unemployment and formal work within the country, the economic damages of the companies, as well as the characteristics and benefits of the existence of a public policy with respect to this situation.

The scope, burdens and benefits generated by the establishment of NOM-035 are presented, determining the critical points in its application, which is mandatory for all companies. The results of the economic analysis of the pandemic are reviewed, analyzing the most relevant aspects and damages for the companies and also verifying the function that a public policy has, which contraventions and benefits could be given, trying to give an answer to the detected problematic, being an option to reincentivize the economy of the Country at this time.

\section{2. - Legal aspect of NOM-035-STPS-2018}

The NOM-035-STPS-2018 Psychosocial Risk Factors at Work-Identification, Analysis and Prevention (NOM-035). It is created through international agreements in which Mexico in response to this treaty, adopts measures so that companies are regulated by labor regulations in order to establish guidelines that can identify psychosocial risk factors, as well as to promote a favorable climate in the workplace.

This measure is mainly promoted by the International Labor Organization (ILO), since this labor problem is widespread in developed and developing countries. (Zarka-Martres, 2001). The legal framework includes the Political Constitution of the United Mexican States (CPEUM), the Federal Labor Law (LFT), the Mexican Official Standards, and the regulations of the Federal Secretariat of Occupational Safety and Health, which regulate current obligations. In its Constitutional Article 123 states, that employers shall be obliged to observe according to the nature of their business the legal precepts of safety and hygiene. (José \& Fol, 2018); likewise the LFT stipulates that decent and dignified work must offer optimal safety conditions to prevent risks, as well as the obligations of employers to operate workplaces in accordance with the exposures established in the regulations of the Secretary of Safety and Health at Work and in the Mexican official standards on safety, health and environment; as well as the obligations of workers to observe these provisions.(Eladio, 2021)

Article 512 of the LFT states that the federal authority will identify the measures necessary to prevent occupational hazards and ensure that the conditions are present to ensure the life and health of workers, such power of the federal authority can be found in the regulations, as well as in the forty-four Mexican Official Standards on Occupational Safety and Health, which are those issued by the STPS. (Pérez \& Fol, 2021).

The objective of NOM-035 is to establish which are the elements to identify, analyze and prevent psychosocial risk factors, as well as to promote a favorable organizational environment in workplaces, and that these resources are mentioned below in the following table. 


\begin{tabular}{|c|c|}
\hline $\begin{array}{c}\text { Identification and } \\
\text { analysis of } \\
\text { psychosocial risk } \\
\text { factors }\end{array}$ & $\begin{array}{c}\text { Organizational } \\
\text { environment how it is } \\
\text { achieved }\end{array}$ \\
\hline $\begin{array}{l}\text { Working environment } \\
\text { conditions }\end{array}$ & $\begin{array}{l}\text { The sense of belonging of the } \\
\text { workers in the organization, } \\
\text { being committed to }\end{array}$ \\
\hline workloads that exceed & $\begin{array}{l}\text { Training for the proper } \\
\text { performance of the assigned } \\
\text { tasks to the extent of what he } \\
\text { knows what to do, so that he } \\
\text { is able to perform the work. }\end{array}$ \\
\hline $\begin{array}{l}\text { lack of control over the } \\
\text { work, more workloads }\end{array}$ & $\begin{array}{l}\text { The precise definition of } \\
\text { responsibilities for the } \\
\text { organization's members }\end{array}$ \\
\hline $\begin{array}{l}\text { Working hours and } \\
\text { shift rotation, which } \\
\text { exceed those } \\
\text { established by the } \\
\text { LFT, affect the worker. }\end{array}$ & $\begin{array}{l}\text { Proactive participation and } \\
\text { communication among its } \\
\text { members. }\end{array}$ \\
\hline $\begin{array}{l}\text { Interference with the } \\
\text { work-family } \\
\text { relationship }\end{array}$ & $\begin{array}{l}\text { Adequate distribution of } \\
\text { workloads with regular work } \\
\text { days }\end{array}$ \\
\hline $\begin{array}{l}\text { negative leadership } \\
\text { with complicated and } \\
\text { heavy environment }\end{array}$ & $\begin{array}{l}\text { The evaluation and } \\
\text { recognition of performance, } \\
\text { to say what a good job was } \\
\text { done so that they feel a sense } \\
\text { of belonging. }\end{array}$ \\
\hline $\begin{array}{l}\text { workplace violence in } \\
\text { the different types of } \\
\text { employer attitudes }\end{array}$ & \\
\hline
\end{tabular}

Table 1 Own elaboration of Psychosocial Risk Factors and Organizational Environment

Source: (Diario Oficial de la Federación, 2021)

The obligation of the standard comes into force in two parts, one is from October 23, 2019 which is already implemented in the workplaces in terms of prevention policy, in the identification of workers exposed to severe traumatic events and the dissemination of information. The second part, which will be in force as of October 23, 2020, provides for the identification and analysis of psychosocial risk factors in the evaluation of the organizational environment and the measures for control actions, the practice of medical examinations and records.

All companies that have workers, must implement NOM-035 and depending on the size of the company will have to show documentary evidence in the workplace as follows:

\section{1-15 Workers}

- Establish policies and measures to prevent Psychosocial Risk and Workplace Violence and to promote a Favorable Organizational Environment.
- $\quad$ Identify and analyze psychosocial risk factors and workplace violence.

Identify workers who were subjected to severe traumatic events.

- Disseminate information among workers about the analysis, results and preventive and corrective actions on psychosocial risk factors, workplace violence and the promotion of a favorable organizational environment.

\section{6 - 50 Employees}

- Establish policies and measures to prevent Psychosocial Risk and Workplace Violence and to promote a Favorable Organizational Environment.

- Identify and analyze psychosocial risk factors and workplace violence.

- $\quad$ Identify workers who were subjected to severe traumatic events.

- Disseminate information among workers about the analysis, results and preventive and corrective actions for psychosocial risk factors, workplace violence and the promotion of a favorable organizational environment.

- Conduct medical examinations for workers who have been found to have a psychosocial disorder that could have repercussions on their physical health.

\section{1 or more workers}

Apply each and every one of the requirements of NOM-035-STPS.

IMSS, in accordance with the World Health Organization, states that health risks in the workplace and psychosocial stress cause occupational diseases and can aggravate other health problems, as well as employment conditions, occupation and position in the hierarchy of the workplace can also affect health due to the psychological pressure that may be exerted. People who work under pressure or in precarious employment conditions are likely to smoke more, engage in less physical activity, and have an unhealthy diet. Work-related noncommunicable diseases, as well as heart disease and depression caused by occupational stress lead to increasing rates of illness and prolonged sick leave, which is a national health problem and a public expense (IMSS, 2020). 
The Social Security Law establishes that it will be in charge of dictating the incapacities of the workers, but it does not mention psychosocial causes as one of them, creating a problem or void that generates inconsistency, since it is necessary to contemplate the diseases and their procedure, there is treatment for problems of this nature, at labor level only unpaid leave and psychological treatment to overcome it are dictated. This institution will be in charge of providing psychological support to workers. (LFT AND LSS, 2021).

The non-compliance with the established guidelines of NOM-035 are penalties that through ordinary inspections are applied to the extent of the offense, and such fines are determined in Units of Measurement and Updating (UMA), which are from 250 to 5,000 UMA and these can be cumulative when not complied with; therefore, the STPS is empowered in the review to conduct audits and scrutiny of compliance.

\section{SARS-CoV-2/ COVID 19}

In addition to the application of NOM-035, the pandemic generated by COVID-19 complicates this process.

This virus was identified in Wuhan, China, was registered in December 2019, which is a severe acute respiratory syndrome coronavirus, causes a disease of almost immediate transmission, which can spread from person to person, it is considered to be a pandemic since (Center for Disease Control and Prevention, 2021), as of September 2021 there is an estimated number of 231 . 820,802, this number is changing since to date it has not been possible to stop this disease, and an approximate of 4,748,055 deaths were registered as a result of COVID-19 (Johns Hopkins University \& Medicine, 2021), the figures in Mexico are equally alarming, since to date there are $3,847,368$ cases of contagion (CONACYT, 2021)., this type of virus has been considered one of the most harmful worldwide.

Coronavirus (COVID-19) has impacted millions of people around the world. From a business perspective, the coronavirus affected a large number of entrepreneurs, but at the same time brought opportunities for renewal. (Rincon, 2020).
According to data from the National Institute of Statistics and Geography (INEGI), through the Telephone Survey of Occupation and Employment (ETOE, 2020) formal and informal companies, closed or temporarily suspended their activities, due to the pandemic. It generated almost $30 \%$ of formal unemployment rate and an increase in the informal occupation to almost twenty-three million people, representing almost $52 \%$ of the country's labor occupation.

If we talk about the economic sectors of the country, the primary sector is in difficult times, as it is making a heroic effort to stay afloat (Román, 2020).

The explanation is very simple, it is due to the impact caused by the closing of borders for exports of farm products, in addition to the change in the need to purchase products with longer expiration dates due to the uncertainty of the people.

The service sector suffered an impact on tourism in states such as Quintana Roo and Baja California Sur, to mention a few. The economic crisis generated by the coronavirus has nothing to do with previous recessionary periods in history. It is basically a consequence of the confinements and social distancing measures enacted to curb contagions and not precisely the imbalance in the financial systems. Moreover, it attacked modern economies, i.e. the service sector, with major consequences, particularly for employment, which was much more affected than production in general. Therefore, if vaccination is the solution to the health unknowns, the economy should be revived. The IMF (International Monetary Fund), in its latest autumn forecasts, estimates a $5.2 \%$ growth for world GDP in 2021 compared to a $4.4 \%$ drop in 2020. (El País, 2020)

To face the pandemic crisis, the Mexican Government has undertaken a series of short and long-term financial measures aligned with the fundamental purpose of maintaining the balance of macroeconomic variables, with positive results for the country's economy in a global economy that has suffered economic and health setbacks, which Mexico has been able to weather. This economic policy has allowed the country to maintain a stability that had not been seen in previous decades. (Bank of Mexico, 2020) 
In a press release, Expansión (Expansión, 2020) assures that the Mexican economy has suffered the most serious crisis in the last 100 years, announcing more than 10 million new poor people, all this, due to the COVID-19 pandemic. At the same time, one million small and medium-sized businesses have now closed. Gómez in his paper (Gómez, 2021) mentions how the year 2020 started with $2.83 \%$ positioning the country in one of the lowest inflation of the last ten years. However, as of April 2021, inflation would begin to rise, reaching a maximum of $4.09 \%$ at the end of October of the same year. This is due to several circumstances caused by the pandemic, such as the shortage of basic food basket products, since there have been severe difficulties in the production of goods and also complications in the logistics to transport these products.

Economic growth is measured through the variation of the Gross Domestic Product (GDP). That is, when a country produces more goods and services than the previous year, using the same number of resources, it means that it had a higher consumption, therefore, it generated higher income. At the end of 2019 the country reached a negative growth of $-0.1 \%$, and at the beginning of 2020 a growth of $2 \%$ was estimated for the same, however, due to the pandemic causes a shutdown of the economy which causes the Mexican economy to fall by $9.9 \%$. (Gómez, 2021) According to an article published by FORBES magazine (FORBES, 2021) the Latin American region was the most affected with a loss of 39 million jobs, with Mexico presenting a reduction of $12.5 \%$.

The Covid-19 pandemic reduced by $8.8 \%$ the number of working hours in the world in 2020 , or the equivalent of 255 million jobs, highlighted today a new report of the International Labor Organization (ILO) that foresees a "slow, uneven and uncertain" recovery of the labor market in 2021. The loss of income from labor last year was similar, at 8.3 percent, equivalent to 3.7 trillion dollars (3 trillion euros) or 4.4 percent of world GDP.

The 255 million jobs "lost" (in many cases it was actually a reduction in the working hours of people still employed) represents an impact four times greater than that caused by the global financial crisis of 2009, the ILO pointed out.
It should be noted that, despite the high figures, the loss of working hours considered by the ILO for the whole of 2020 was significantly lower than that calculated in the second quarter of last year (400 million jobs) and the third (almost 500 million).

In this respect, it was women who were most affected by the unemployment resulting from the pandemic.

\section{Impact of covid-19 on Unemployment in Mexico}

According to official information from the United Nations in Mexico, prior to the pandemic, women reported that their male colleagues had more time and facilities to go on business trips, join projects, and attend afterhours events that are key to professional growth. There was also a marked pay gap with men, more facilities for men to reach decision-making positions, and growth facilities for those without children. Motherhood was seen as an element that has held back their professional growth.

With COVID-19 confinement, some men were placed in a position of comfort with respect to women.

In this regard, $80.5 \%$ of women with daughters and sons under 10 years of age reported increased unpaid work, compared to $76.8 \%$ of women without children; in addition, $56 \%$ of women reported feeling more tired than before the pandemic, compared to $39 \%$ of men in this situation.

The COVID-19 pandemic also significantly impacted the health of working mothers, who reported physical and mental exhaustion. Most expressed that fulfilling the work and care around the home represented an overload. (UN Mexico, 2021)

\begin{tabular}{|l|r|r|}
\hline & Women & Men \\
\hline No gainful employment & $80.9 \%$ & $26.2 \%$ \\
\hline $\begin{array}{l}\text { Work outside the home without the } \\
\text { possibility of a home office }\end{array}$ & $24.8 \%$ & $45.5 \%$ \\
\hline Work from home & $4.1 \%$ & $2.3 \%$ \\
\hline $\begin{array}{l}\text { Work outside the home with the } \\
\text { possibility of a home office. }\end{array}$ & $12.2 \%$ & $22.5 \%$ \\
\hline
\end{tabular}

Table 2 Employment status prior to the pandemic Source: Authors' elaboration based on UN México (2021) 


\section{4.- Public Policies}

It is clear that in all economic activity the most valuable asset is human capital, the engine that makes companies and the economy itself grow, and speaking of companies is determined, the most important expense in its expenditures, so it is also essential to take into account the labor situation of people working in a company, it is substantial, since from the "organizational health" is the performance and growth of the organization.

In the current situation, when analyzing the companies and their panorama, we have determined the important points to know, such as the regulations implemented in Norm 035, and the situation that afflicts this sector due to the pandemic of COVID-19, the companies are trying to resist these changes and adapting to the modality at home, the situations generated by the disease of COVID-19, it has been considered that the situation of the companies is not a new one.

The situations generated by the COVID19 disease have been considered to cause emotional disorders from being confined by the pandemic, loss of family members, or the same fear of being infected, mental health experts consider that there is still uncertainty due to the probable mental illnesses that have not been fully determined, Pedro Rodríguez (Cortés, 2021), specialist in mental health and member of the General Council of Psychology of Spain, assures that all of us will present some psychological reaction and consequences in this sense, it can be from an obsessive compulsive disorder (OCD), phobias, hypochondrias, among others; This is alarming, because when talking about a worker, it will be difficult to define this type of disorder that is monitored by the NOM035, and determine whether it is generated from work situations or family situations or outside the workplace, which brings with it the implementation of extra actions to the application of the standard, such as psychology specialists who are aware of the ailments that occur in the corporate, It is for all these aspects, the need to implement measures to facilitate this process, that companies that represent a substantial contribution to the Mexican economy, have an incentive or a security that they can cope with this economic burden and all that it entails.
A public policy would be a means to give certainty to this private sector, through this measure a clear panorama could be established for the businessmen, which would allow them to have all the bases to carry out this attention to the employees, visualizing this regulation as a benefit, which undoubtedly it is, but with a certainty that there is a support from the government that will allow not to skimp in the least, and that in turn can benefit the formality of employment. support from the government that will allow not to skimp in the least, and that in turn can benefit the formality of employment, since it is because of aspects like this that informal employment continues to occur in Mexico. (IDC Online, 2021)

Public policy is the response to the needs or problems of the governed, that is, it is the way in which the State makes its presence felt in the face of the demands faced by the population and in Mexico, it is common for these to be changed or modified by the incoming governments, failing to follow up on the regulations imposed previously; But similarly Public Policies are the way to handle certain issues in the different areas that a government works, whether public policies in health, infrastructure, security, etc.

Ruiz López and Cárdenas (Ruiz,D. and Cárdenas, C., 2018) point out that it is understood to be, a government program, and this can be an answer to work any type of public issue that needs a line for its attention. According to (Bravo, Díaz, \& Meneses, 2021) policies must be designed under coherent criteria, established to achieve the business mission objective, in addition to achieving good productivity; it also seeks efficiency in the investment of resources, in such a way as to allow planning, programming and executing the budget of public entities.

For a Public Policy to be effective, the participation of the governmental body and civil society is needed, since it would be difficult to conceive an action aimed at citizens in which they do not participate. As the function of a Public Policy is clear, which in concrete terms could be determined as the action of directing an activity towards its execution, and that within the analysis of the feasibility of the creation of a Public Policy in compliance with NOM-035, it would be understood that this would be in favor of the companies that will carry out the application of the Standard in their work environment, 
The development of this policy implies having specialized personnel in the initial analysis studies, following up on the failures found and implementing the necessary changes to reduce the psychosocial risks found; However, this does not imply the need for a benefit for those who carry out the regulations, more in the analysis of the pandemic situation that is being experienced today, and the havoc that is being generated and the modifications that companies have had to make.

A public policy in this sense, could be a fiscal policy itself, that encourages some discount for the expenses generated in the institution of specialized personnel or integral actions to attend to the health of employment; with a background of encouraging the formality of employment, since in these circumstances, companies, mostly SMEs, see informality in the employment of their workers, as an ease and a more economical way to carry out their operations.

A policy addressing this situation would bring a benefit in several aspects, it would be an incentive to formalize and give all the labor and legal guarantees to the employees, attending to the norms established for the labor relationship, it would be a great help in public health, since those red spots of labor health would be immediately addressed in the companies, and there would be an advance in the national economy since everyone would be in the formality.

\section{Description of the method}

The research was qualitative of basic type since it contributed to the generation of knowledge, it was non-experimental through an action research design, the information was collected through the collection of documents, it was possible to review a variety of scientific publications that have studied the different topics discussed in this document, mostly international sources specialized in the subject.

The testimonies printed in other investigations were analyzed, which allowed us to have a general overview, showing that there are similarities in the characteristics and problems detected in Latin American countries regarding the impact derived from the application of NOM-035-STPS-2018 and the COVID 19 consequences.

\section{6.- Results}

From the data presented, it is clear that the current economic situation both for the country, citizens and companies is not very encouraging, the numbers shown by international organizations give a clear picture of the recession that has been generated by the virus, and likewise shows the need to make immediate decisions for sustainability and respect for the ecosystem from all perspectives, One of these is the attention to people, and on this occasion the working population, which has been shown that in Latin America, and specifically in Mexico, precarious working conditions prevail, hence the need to create standards to ensure a healthy employment, so that the 035 Standard is the answer to this need.

Still, the institutions do not have statistical data on the problems of psychosocial risk factors, since the second phase of the standard is just going to be implemented as mandatory, it is in its initial phase, and it is from this year, October 23, 2021, where you can have a database, which allows to measure the degree to which the requirements of psychosocial health are met according to the objectives of the standard, and to ensure the rights of workers.

The Norm has been implemented, in the possibility of the companies and with the caveats of the lack of information for this task; there are doubts about the actions since not even the same institutions such as the Social Security have updated their occupational diseases, since the diseases that are sought to be detected and treated by the NOM-035, are not yet considered as occupational diseases, so there is no occupational risk or a defined procedure for their administrative treatment.

On the other hand, the pandemic in the last two years presents important challenges for companies in Mexico, as they respond to a serious financial and operational crisis with a high degree of responsibility to keep their businesses operational, having to implement a series of actions not only to comply with the restrictions of the sanitary authorities, but they were also able to design different strategies to continue with their productive activities, despite the absence of financial incentives that most of them did not have access to. 
The lack of federal support to these businessmen caused the unemployment rate to skyrocket, since even with the businesses closed, they had to continue with the compliance of the employer-employee obligations, which is why this generated a number of business closures, specifically those that did not have financial leverage to help them cushion the crisis caused by the pandemic, and also the need to operate informally such as informal employment, having employees without any type of guarantee and benefits.

It was also found a contradiction, since the NOM-035, seeks to find, prevent and treat psychosocial damage generated in companies either by their organizational climate or its very operation, this is complicated when we talk about the aftermath of the disease, which are these same, it is difficult to define whether the damage detected in the employee, comes as a result of their work stress or tension, due to their workload; or it is generated by some personal situation of affectation for having suffered COVID-19 or someone of his family has been affected, mechanisms of attention of bottom inside the companies are needed, activities or actions that encourage the source of work, that give tranquility and attention to the employees, that this is summarized in expenses for the labor unit.

\section{7.- Conclusions}

In view of this panorama, the public sector in Mexico has to look for answers to these needs, it is clear that the application of NOM-035 is decisive in view of the legal authority that it implies, there is no other option but to comply with it, there have been many situations overcome by small and medium-sized companies, not excluding some multinationals, There have been many situations that Small and Medium-sized companies, without excluding some multinationals, have had to deal with on the burden they face day by day, so some type of benefit, translated into some administrative facility or economic remission would be a great help for those who are in the formality, a public policy translates into a public expense, or a decrease of income in the government's coffers,
It is very useful to carry out an in-depth review of the great help that would be generated if, in the face of an economic benefit, the companies that are formal and informal today align themselves with this measure and perhaps go further in the prevention and solution of the damage to occupational health in the organization, This would be a public policy that would help to reactivate and maintain the economy, lightening the burden on companies and benefiting the working population.

\section{8.- Proposals}

- $\quad$ It is proposed that the Government carry out actions aimed at supporting companies that have retained their employees in times of pandemic, seeking benefit mechanisms, such as remission of taxes related to payroll or social security contributions.

- Generate clear guidelines for the deduction of expenses related to the prevention and attention that NOM-035 manages, giving certainty to proceed in actions such as implementing an area of psychological services within the company, offering benefits related to sports or recreational activities for employees, and other actions aimed at the prevention and attention of psychosocial risks.

- Implement actions on the part of the STPS, of a rigorous follow-up for those companies that bring detected situations, so that these receive direct support before the involved institutions such as the IMSS.

- $\quad$ Promote advertising campaigns by the STPS, in which information is disseminated to contribute to the reduction or elimination of psychosocial risks.

- Offer workshops to workers, to sensitize them to the importance of the work environment and with this they can detect risk situations, helping the company to find strategies for balance in the workplace. 


\section{8. - References}

Centro para el Control y la Prevención de Enfermedades. (2021). Centro para el Control y la Prevención de Enfermedades CDC. Recuperado el julio de 2021, de COVID- 19: https://www.cdc.gov/coronavirus/2019ncov/hcp/non-us-settings/overview/indexsp.html

LFT Y LSS. (2021). Ley Federal de Trabajo y Leyes de Seguridad Social. México.

CONACYT. (septiembre de 2021). Datos COVID-.19. Obtenido de COVID 19 México: https://datos.covid-19.conacyt.mx/

Cortés, N. (23 de octubre de 2021). Secuelas psicológicas, trastornos y traumas después de vivir el coronavirus. Obtenido de ConSalud.es: Secuelas psicológicas, trastornos y traumas después de vivir el coronavirus

Banco de México. (Mayo de 2020). Políticas Económicas Consideradas en México. Obtenido de Banco de México: https://www.banxico.org.mx/publicaciones-yprensa/informes-

trimestrales/recuadros/\%7B455A13D4-524F84CE-704E-8045ED092A0C\%7D.pdf

Bravo, L. S., Díaz, B. C., \& Meneses, G. J. (10 de febrero de 2021). Universidad de Bogotá Jorge Tadeo Lozano. Recuperado el noviembre de 2021, de Propuesta de implementación de la política de gestión presupuestal y eficiencia del gasto público en la empresa de servicios públicos de Sandoná, EMSAN E.S.P. Año 2021: https://expeditiorepositorio.utadeo.edu.co/handl e/20.500.12010/18059

Diario Oficial de la Federación. (2021). DOF: 23/10/2018. Obtenido de https://www.dof.gob.mx/nota_detalle.php?codi go $=5541828 \&$ fecha $=23 / 10 / 2018$

El País. (27 de diciembre de 2020). Una Inyección de Esperanza Económica. Obtenido de El País: https://elpais.com/economia/202012-27/2021-una-inyeccion-de-esperanzaeconomica.html

Eladio, C. G. (2021). Ley Federal de Trabajo y Leyes de Seguridad Social . México: Tax Editores.
ETOE. (2020). Resultados de la Encuesta Telefónica de Ocupación y Empleo (ETOE). Obtenido de INEGI: https://www.inegi.org.mx/investigacion/etoe/

Expansión. (28 de Diciembre de 2020). México termina 2020 con la crisis económica más severa en 100 años. Obtenido de Expansión: https://expansion.mx/economia/2020/12/28/me xico-termina-2020-crisis-economica-massevera-100-anos

FORBES. (25 de enero de 2021). FORBES. Recuperado el octubre de 2021, de https://www.forbes.com.mx/economiapandemia-covid-19-255-millones-empleos2020/

Gómez, L. A. (1 de Febrero de 2021). Perspectiva económica 2021. Obtenido de El Heraldo de Chihuahua: https://www.elheraldodechihuahua.com.mx/ana lisis/perspectiva-economica-20216309205.html

IDC Online. (20 de agosto de 2021). Crece empleo en México, pero con trabajo informal. Obtenido de IDC Online: https://idconline.mx/laboral/2021/08/20/creceempleo-en-mexico-pero-con-trabajo-informal

IMSS, P. I.-2. (2020). IMSS. Obtenido de http://www.imss.gob.mx/sites/all/statics/pdf/tra nsparencia/rendicion/PIIMSS-2020-2024VF.pdf

Johns Hopkins University \& Medicine. (septiembre de 2021). Johns Hopkins University \& Medicine. Obtenido de Coronavirus Resource Center: https://coronavirus.jhu.edu/map.html

José, P. C., \& Fol, O. R. (2018). CPEUM. En Constitución Politica de los Estados Unidos Mexicanos (pág. 206). Tax Editores.

ONU México. (septiembre de 2021). Información Oficial de las Naciones Unidas. Recuperado el octubre de 2021, de https://coronavirus.onu.org.mx/por-covid-19mujeres-enfrentaron-mayor-desempleo-cargade-trabajo-domestico-y-enfermedades-mentales

Pérez, C. J., \& Fol, O. R. (2021). Ley Federal del Trabajo. Tax Editores. 
Rincón, S. (Agosto de 2020). Pandemia del COVID 19 ¿Un buen momento para emprender? Obtenido de México: https://www.forbes.com.mx/emprendedorespandemia-covid-19-momento-para-emprender/

Román, S. d. (28 de abril de 2020). El impacto de la COVID-19 en la agricultura. Obtenido de iagua: https://www.iagua.es/blogs/sergioroman/impacto-covid-19-agricultura-0

Ruiz,D. y Cárdenas, C. (2018). ¿Que es una política Pública? Recuperado el septiembre de 2021, de Universidad Latina de América: https://ti.unla.edu.mx/iusunla18/reflexion/QUE $\% 20 \mathrm{ES} \%$ 20UNA\%20POLITICA\%20PUBLIC A\%20web.htm

Zarka-Martres, M. H. (2001). Las normas internacionales del trabajo un enfoque global. En M. H. Zarka-Martres. Ginegra Suiza: Malta. 